\title{
tratamiento de las superficies metálicas oxidadas que se van a pintar
}

!Couche d'apprêt avant peinture aux résines vinyliques, destinée à être déposée sur une surtace rouillé)

EDITUKLAL.

De: «Journal de la Construction de la Suisse Romande», año XXXa, núm. 1, enero 1957, pág. 31

Corrientemente, cuando se va a proceder a pintar una superffele metálica oxidada es preciso proceder a un decapado de la misma. En la actualidad no es necesario realizar tal operación, sino que basta aplicar una primera mano de un nuevo producto aparecido recfentemente en el mercado, con el nombre de "Rustbond primer".

La forma de proceder es senclla. En primer lugar se fróta la superficle en cuestión con un cepillo adecuado, con objeto de eliminar las escamas de herrumbre que no se encuentren ftrmemente adheridas. Después se aplifa la mano de "Rustbond primer". Esta capa, al secarse, forma una película que se adhiere fuertemente al acero y que, al mismo tiempo, aprisiona a la herrumbre, proteglendo al metal contra toda oxidación posterior. Esta pintura moja perfectamente a la herrumbre, aunque sin disolverla, de modo que las particulas de óxido de hierro juegan, en cierto modo, el papel de pigmento.

Este nuevo producto es apto para formar una primera capa en las placas metálicas oxidadas, destinadas a ser recubiertas, postertormenie, mediante una pintura o un barniz vinilico, con el fin de impedir la separaclón de esta pintura.

S. F. S. 